\title{
Haloperidol as an anti-emetic for Cannabis Hyperemesis Syndrome in the ED
}

\author{
Aleksandar Trajkovski ${ }^{1}$ (1) $\cdot$ Eddy Lang $^{2}$
}

Received: 14 January 2021 / Accepted: 23 March 2021 / Published online: 9 April 2021

(C) The Author(s), under exclusive licence to Canadian Association of Emergency Physicians (CAEP)/ Association Canadienne de Médecine d'Urgence (ACMU) 2021

Full Citation: Ruberto AJ et al. Intravenous Haloperidol Versus Ondansetron for Cannabis Hyperemesis Syndrome (HaVOC): A Randomized, Controlled Trial. Annals of Emergency Medicine. 2020. Article in press. https://doi.org/10.1016/j.annemergmed.2020.08.021.

Abstract Link: https://pubmed.ncbi.nlm.nih.gov/33160 $719 /$.

Article Type: Therapy

Ratings: Methods: 3/5, Usefulness: $3 / 5$

\section{Introduction}

\section{Background}

Cannabis hyperemesis syndrome presents to the Emergency Department (ED) with cycles of intractable nausea, vomiting and abdominal pain which are often refractory to traditional anti-emetics.

\section{Objectives}

Ruberto and colleagues evaluated whether intravenous Haloperidol $(0.05 \mathrm{mg} / \mathrm{kg}$ or $0.1 \mathrm{mg} / \mathrm{kg})$ was superior to intravenous Ondansetron $(8 \mathrm{mg})$ in ED patients presenting with cannabis hyperemesis syndrome.

Aleksandar Trajkovski

Alt118@usask.ca

Eddy Lang

eddy.lang@albertahealthservices.ca

1 University of Saskatchewan, Saskatoon, SK, Canada

2 University of Calgary, Calgary, $\mathrm{AB}, \mathrm{Canada}$

\section{Methods}

\section{Design}

HaVOC was a randomized, triple-blind 3-period crossover with block randomization stratified by site to either Haloperidol or Ondansetron, with subsequent crossover to the alternative after a 7-day washout.

\section{Setting}

Two academic EDs in Ontario.

\section{Subjects}

Patients were $>18$ years old, a working diagnosis of cannabis hyperemesis syndrome ( $\geq 3$ episodes of cyclic emesis, separated by $>1$ month during preceding 2 years), near-daily inhalational cannabis use $\geq 6$ months, with $>2$ h ongoing retching.

\section{Outcomes}

Primary outcome was change in pain and nausea scores at $2 \mathrm{~h}$ versus baseline. Secondary outcomes included treatment success (score $<2 \mathrm{~cm}$ at $\geq 2 \mathrm{hrs}$ ), rescue anti-emetic, time to discharge.

\section{Main results}

A total of 30 patients were randomized for period 1 , with 13 allocated to Haloperidol $(\mathrm{n}=7$ for $0.1 \mathrm{mg} / \mathrm{kg}$ and $\mathrm{n}=6$ for $0.05 \mathrm{mg} / \mathrm{kg}$ ) and 17 to Ondansetron. The Haloperidol group was treated as one for analysis, and a difference of $>2 \mathrm{~cm}$ in VAS was defined as clinically significant. There were no significant baseline demographic differences between groups. 


\begin{tabular}{|c|c|c|c|c|}
\hline $\begin{array}{l}\text { Statistical } \\
\text { significance }\end{array}$ & $\begin{array}{l}\text { Outcomes } \\
\text { (at } 2 \mathrm{~h} \text { ) }\end{array}$ & $\begin{array}{l}\text { Halop- } \\
\text { eridol, cm } \\
\text { (SD) }\end{array}$ & $\begin{array}{l}\text { Ondanse- } \\
\text { tron, cm } \\
\text { (SD) }\end{array}$ & $\begin{array}{l}\text { Difference } \\
\mathrm{cm}(95 \% \mathrm{CI})\end{array}$ \\
\hline Yes & $\begin{array}{l}\text { Mean } \\
\text { change in } \\
\text { combined } \\
\text { score }\end{array}$ & $-4.6(2.5)$ & $-2.3(2.4)$ & $\begin{array}{c}-2.3(-4.2 \\
\text { to }-0.5)\end{array}$ \\
\hline Yes & $\begin{array}{l}\text { Mean } \\
\text { change } \\
\text { in nausea } \\
\text { score }\end{array}$ & $-5.0(2.7)$ & $-2.4(2.4)$ & $\begin{array}{c}-2.5(-4.4 \\
\text { to }-0.6)\end{array}$ \\
\hline No & $\begin{array}{l}\text { Mean } \\
\text { change in } \\
\text { abdominal } \\
\text { pain score }\end{array}$ & $-4.3(3.0)$ & $-2.1(2.8)$ & $\begin{array}{l}-2.2(-4.4 \\
\quad \text { to } 0)\end{array}$ \\
\hline No & $\begin{array}{l}\text { Treatment } \\
\text { Success } \\
(\mathrm{N}, \%)\end{array}$ & $7(53.8)$ & $5(29.4)$ & $\begin{array}{l}24 \%(-16 \text { to } \\
59)\end{array}$ \\
\hline
\end{tabular}

Only 9 patients (4 haloperidol, 5 ondansetron) reported 24/48 h VAS scores. No period 2 or 3 analyses were done due to $<25 \%$ patient crossover. Safety outcomes in Haloperidol $(0.1 \mathrm{mg} / \mathrm{kg})$ group found 1-episode akathisia (13\%), and 3 (38\%) return visits (1 ongoing nausea, 2 dystonic reactions). The Ondansetron group had 6 (33\%) return visits all for ongoing nausea.

\section{Appraisal}

\section{Strengths}

- Strong design as a triple-blind RCT with crossover

- Stratified randomization, concealed allocation

- Well-defined inclusion and exclusion criteria

- Use of validated VAS

- Pre-specified outcomes

- No loss to follow up for primary outcome at $2 \mathrm{~h}$

- Patient-oriented primary outcome

- Secondary outcomes both efficacy and safety

\section{Limitations}

- Overly complex study design not achieved

- Very small convenience sample may lead to chance group imbalances at baseline

- Early termination may overestimate treatment effects

- Loss to follow up at 24/48 h time points limits estimate of effectiveness beyond $2 \mathrm{~h}$

- Unpaired analysis without crossover

- Complicated graphic representation of results

- No discussion of alternative traditional anti-emetics

\section{Context}

Patients presenting to the ED with cannabis hyperemesis syndrome are often refractory to traditional anti-emetics, which makes treatment and disposition challenging. They receive multiple doses of anti-emetics and analgesics with minimal relief. A subset have endorsed relief from hot showers leading to trials of topical capsaicin [1]. Case reports and small case series have identified Haloperidol as a potential treatment $[1,2]$. A prior RCT found Haloperidol superior to Ondansetron, however, this was done for post-operative nausea and vomiting [3]. HaVOC was the first RCT to compare Haloperidol to Ondansetron for cannabis hyperemesis syndrome in an ED setting.

\section{Bottom line}

Single-dose Haloperidol at $0.05 \mathrm{mg} / \mathrm{kg}$ or $0.1 \mathrm{mg} / \mathrm{kg} \mathrm{IV}$, alongside intravenous crystalloid rehydration is superior to single-dose Ondansetron ( $8 \mathrm{mg}$ ) for cannabis hyperemesis syndrome. While evidence beyond $2 \mathrm{~h}$ is limited, Haloperidol leads to clinically significant improvement in nausea and abdominal pain at $2 \mathrm{~h}$ post-dose. Emergency Physicians should consider using Haloperidol among other traditional anti-emetics in the treatment of cannabis hyperemesis syndrome. That being said, more research is required before Haloperidol can be recommended as first-line anti-emetic for cannabis hyperemesis syndrome.

\section{Declarations}

Conflict of interest I do not have any conflicts of interests or financial supports to declare. Dr.Eddy Lang was instrumental in helping to select the article, and provide editorial comments for improvement to the rough and final drafts of this submission. He has agreed to submission and publishing of this review.

\section{References}

1. Jones J, Abernathy K. Successful treatment of suspected cannabinoid hyperemesis syndrome using haloperidol in the outpatient setting. Case Rep Psychiatry. 2016. https://doi.org/10.1155/2016/ 3614053].

2. Hickey JC, Witsil JC, Mycyk M. Haloperidol for treatment of cannabinoid hyperemesis syndrome. Am J Emerg Med. 2013;31(6):1003.e3-1003.e6. https://doi.org/10.1016/j.ajem.2013. 02.021].

3. Yazbeck-Karam VG, Siddik-Sayyid SM, Barakat HB, et al. Haloperidol versus ondansetron for treatment of established nausea and vomiting following general anesthesia: a randomized clinical trial. AnesthAnalg. 2017;124(2):438-44. 